\title{
Pre-treatment prognostic nutritional index may serve as a potential biomarker in urinary cancers: a systematic review and meta-analysis
}

\author{
Feng $\mathrm{Qi}^{\dagger}$, Xiang Zhou ${ }^{\dagger}$, Yi Wang $^{\dagger}$, Yamin Wang, Yichun Wang, Qijie Zhang, Rong Cong, Jie Yang ${ }^{*}$ \\ and Ninghong Song* ${ }^{*}$
}

\begin{abstract}
Background: To investigate the potential prognostic role of pre-treatment prognostic nutritional index (PNI) in urinary cancers.

Methods: Relevant articles were searched comprehensively from PubMed, Embase and Web of Science, up to November 2018. The pooled hazard ratios (HRs) with 95\% confidence intervals (Cls) were extracted to evaluate their associations.

Result: A total of 12 related articles including 6561 patients were ultimately enrolled. Our results indicated that a relatively lower level of pre-treatment PNI was associated with decreased OS, CSS/DSS and DFS/RFS/PFS (pooled $\mathrm{HR}=1.68,95 \% \mathrm{Cl} 1.45-1.95$; pooled $\mathrm{HR}=1.57,95 \% \mathrm{Cl} 1.33-1.86$; pooled $\mathrm{HR}=1.75,95 \% \mathrm{Cl} 1.53-1.99$, respectively). Subsequent stratified analysis by cancer type for OS showed that PNI could also be a predictor no matter in renal cell cancer (RCC) or bladder cancer (BC) (pooled $\mathrm{HR}=1.65,95 \% \mathrm{Cl} 1.37-1.97$ and pooled $\mathrm{HR}=1.67,95 \% \mathrm{Cl} 1.20-2.33$ ). Similar results could be found in DFS/RFS/PFS (RCC: $H R=1.81,95 \% \mathrm{Cl} 1.54-2.13$ and $\mathrm{BC}: \mathrm{HR}=1.68,95 \% \mathrm{Cl} 1.32-2.12$ ) and in CSS/DSS (RCC: $\mathrm{HR}=1.50,95 \% \mathrm{Cl} 1.23-1.82$ and upper tract urothelial carcinoma: $\mathrm{HR}=1.61,95 \% \mathrm{Cl} 1.13-2.28$ ). As for the treatment subgroup, a relatively lower level of PNI could also be a positive predictor for OS (surgery: $\mathrm{HR}=1.64,95 \% \mathrm{Cl} 1.40-1.93$; target therapy: $\mathrm{HR}=1.88,95 \% \mathrm{Cl} 1.34-2.63$ ) and DFS/RFS/PFS (surgery: $\mathrm{HR}=1.69,95 \% \mathrm{Cl}$ 1.47-1.95; target therapy: $\mathrm{HR}=2.14,95 \% \mathrm{Cl} 1.50-3.05)$.
\end{abstract}

Conclusion: The outcomes of us shed light on that elevated pre-treatment PNI was positively associated with OS, CSS/DSS and DFS/RFS/PFS, indicating that it could be an independent prognostic factor in urinary cancers.

Keywords: Prognostic nutritional index, PNI, Urinary cancer, Meta-analysis

\section{Background}

Urinary cancers, as a term mainly consisting of prostate cancer (PC), bladder cancer (BC), renal cell cancer (RCC), are much more common in men than in women and the incidence of these tumors ranks the second, fifth and seventh most commonly diagnosed cancer in the United States, 2017 [1]. Generally, the mainstay of therapy for localized urological tumors is surgical resection,

\footnotetext{
*Correspondence: yj197912@163.com; songninghong_urol@163.com ${ }^{\dagger}$ Feng Qi, Xiang Zhou and Yi Wang contributed equally to this work Department of Urology, The First Affiliated Hospital of Nanjing Medical
} University, No. 300 Guangzhou Road, Nanjing 210009, China while target therapy is mainly for metastatic cases. Due to the appearance of sipuleucel-T based immunotherapy and the development of molecular target drugs [2, 3], survival of urinary cancer has been greatly improved [4]. However, the prognosis of these tumors is still not satisfying. As for RCC, postoperative recurrence occurs in one-third of patients [5]. Meanwhile, in terms of BC, its 5 -year survival remains $77.9 \%$, even only $5.4 \%$ for distant diseases [6]. Therefore, exploring the prognostic factors for survival, death or recurrence may be of great value to better understand these and help physicians to develop the optimal treatment strategies for patients. 
Prognostic nutritional index (PNI), as a predictor of cancer prognosis, was firstly introduced by Onodera et al. [7] to investigate the potential prognostic role in gastrointestinal malignancy in 1984. Moreover, it had also been validated to be an independent prognostic factor in many other types of tumors, such as hepatocellular carcinoma [8], pancreatic cancer [9], and pleural mesothelioma [10]. Recently, PNI as a prognostic factor in the case of urinary cancer, had gradually gained a lot of interest and accumulating researches considered it to be an independent prognostic factor in urinary tumors, associated with overall survival (OS), progression-free survival (PFS) or cancer specific survival (CSS). However, their results remained inconsistent. Hence, this meta-analysis was conducted systematically to shed light on the relationship between PNI and urinary cancer. Due to the absence of level I evidence guiding the application of PNI in urinary cancers, our results were also anticipated to provide some references for clinical work.

\section{Materials and methods}

\section{Search strategy}

To investigate the potential role of PNI in urinary cancers, relevant articles were searched comprehensively from online databases PubMed, Embase and Web of Science, up to November 2018. The search strategy was consisted of the following keywords in combination with Medical Subject Headings (MeSH) terms and text words: ("prognostic nutritional index" or "PNI") and ("urological tumors" or "prostate cancer" or "renal cell cancer" or "bladder cancer" or "urothelial cancer" or "upper tract urothelial carcinoma") and ("survival" or "recurrence" or "prognosis" or "progress"). This meta-analysis was performed according to the preferred reporting items for systematic reviews and meta-analyses (PRISMA) statement [11] and no language restriction was applied in the selection process.

\section{Inclusion/exclusion criteria}

Articles eventually enrolled in this meta-analysis should meet the following criteria: (1) cohort studies or casecontrol studies; (2) patients were diagnosed with urinary cancers histopathologically; (3) the association of pre-treatment PNI with specific endpoint (e.g. OS, recurrence-free survival (RFS), PFS, disease-free survival (DFS), disease-specific survival (DSS) or CSS; (4) available data by means of hazard ratios (HRs) with $95 \%$ confidence interval (CIs) should be provided. Exclusion criteria were as follows: (1) lack of accurate data; (2) letter, review and case report; (3) simple description without comparison. Additionally, only the largest sample size study was included if the same series of research were used in various articles.

\section{Data extraction and quality assessment}

The whole selection process was performed independently by two blind investigators (F.Q and X.Z). Disagreements were addressed by consultation with a third reviewer (Y.W). Following data were extracted from articles based on standard form: first author's name, year of publication, country, cancer type, study design, treatment methods, sample size (number of total patients), PNI cut-off values, endpoints, HRs with 95\% CIs and followup. Data were extracted from Kaplan-Meier curves to extrapolate HRs with 95\% CIs using previously described methods, if it could not be directly obtained from each article $[12,13]$. Methodologic quality of each included articles was assessed by the Newcastle-Ottawa Scale (NOS) (http://www.ohri.ca/programs/clinical_epide miology/oxford.htm), which was one of the most useful scale to evaluate the quality of non-randomized studies [14]. Total quality scores were ranged from 0 to 9 and if the final score $>6$, we regarded it to be of high quality. Detailed rankings for each study were shown in Table 1.

\section{Statistical analysis}

To investigate the potential role of PNI in urinary cancers, this meta-analysis was conducted based on available data and the pooled HRs with 95\% CIs were utilized to evaluate their efficacy. Cochran's Q test and Higgins $\mathrm{I}^{2}$ statistic were used to evaluate the heterogeneity. If significant heterogeneity $\left(P<0.10\right.$ or $\left.I^{2}>50 \%\right)$ existed, the random effect model (a DerSimonian-Laird method) would be applied. Otherwise, the fixed effect model (a Mantel-Haenszel method) was adopted [15]. The stability and reliability of the results was determined by sensitive analysis, which was an effective measure to recount the pooled ORs via consecutively excluding each study once a time. Furthermore, publication bias was assessed by Begg's funnel plot and Egger's linear regression test, and $P<0.05$ was considered to be statistically significant [16]. In addition, all statistical data were conducted by Stata software (version 12.0; StataCorp LP, College Station, TX) and Microsoft Excel (V.2007, Microsoft Corporation, Redmond, WA, USA).

\section{Results \\ Study characteristics}

A total of 12 [17-28] articles including 6561 patients were ultimately involved after systematic selection. Flow diagram of literature search and selection process was summarized in Fig. 1. The NOS scores of enrolled articles were all above 6 (Table 1) and the basic characteristics of eligible studies were present in Table 2. All of the studies were retrospective. In terms of tumor type, 6 articles focused on RCC, 3 articles focused on BC, 2 articles 
Table 1 Newcastle-Ottawa quality assessments scale

\begin{tabular}{|c|c|c|c|c|c|c|c|c|c|c|}
\hline \multirow[t]{2}{*}{ Studies } & \multirow[t]{2}{*}{ Year } & \multicolumn{8}{|c|}{ Quality indicators from Newcastle-Ottawa Scale } & \multirow[t]{2}{*}{ Scores } \\
\hline & & 1 & 2 & 3 & 4 & 5 & 6 & 7 & 8 & \\
\hline Cai [18] & 2017 & $\star$ & $\star$ & - & - & $\star \star$ & - & $\star$ & $\star$ & 6 \\
\hline Peng $[25]$ & 2017 & - & $\star$ & $\star$ & - & $\star \star$ & $\star$ & $\star$ & $\star$ & 7 \\
\hline Miyake [24] & 2017 & $\star$ & $\star$ & - & $\star$ & $\star \star$ & - & $\star$ & - & 6 \\
\hline Cui [23] & 2017 & - & $\star$ & - & $\star$ & $\star \star$ & $\star$ & - & $\star$ & 6 \\
\hline Huang [26] & 2017 & $\star$ & - & $\star$ & $\star$ & $\star \star$ & - & $\star$ & $\star$ & 7 \\
\hline Fan [28] & 2017 & $\star$ & $\star$ & - & $\star$ & $\star \star$ & - & $\star$ & $\star$ & 7 \\
\hline Broggi [17] & 2016 & $\star$ & - & $\star$ & $\star$ & $\star \star$ & - & $\star$ & - & 6 \\
\hline Kwon [21] & 2017 & $\star$ & $\star$ & - & $\star$ & $\star \star$ & $\star$ & $\star$ & - & 7 \\
\hline Peng [22] & 2017 & $\star$ & - & - & $\star$ & $\star \star$ & - & $\star$ & $\star$ & 6 \\
\hline Jeon [20] & 2016 & $\star$ & $\star$ & - & $\star$ & $\star \star$ & $\star$ & - & $\star$ & 7 \\
\hline Kim [27] & 2015 & - & $\star$ & $\star$ & - & $\star \star$ & $\star$ & $\star$ & $\star$ & 7 \\
\hline Hofbauer [19] & 2015 & $\star$ & - & $\star$ & $\star$ & $\star \star$ & - & $\star$ & $\star$ & 7 \\
\hline
\end{tabular}

1. Representativeness of the exposed cohort; 2 . Selection of the non-exposed cohort; 3 . Ascertainment of exposure; 4 . Outcome of interest not present at start of study; 5 . Control for important factor or additional factor; 6 . Assessment of outcome; 7. Follow-up long enough for outcomes to occur; 8 . Adequacy of follow up of cohorts

focused on upper tract urothelial carcinoma (UTUC) and only 1 article focused on PC. In the case of treatment type, 9 articles were on surgery and 3 articles were on target therapy. Of all the 12 articles, 9 articles investigated the prognostic role of PNI for OS, 3 for CSS, 3 for DFS, 5 for PFS, 2 for RFS and 2 for DSS. In addition, the cut-off value of PNI applied in each study was varied from each other, ranged from 44.7 to 52.57 .

\section{OS associated with PNI in urinary cancer}

A total of nine eligible studies revealed the prognostic role of pre-treatment PNI in urinary cancer on OS by fixed-effects model with no heterogeneity $(P=0.968$, $I^{2}=0.0 \%$ ). Our results indicated that a relatively lower level of pre-treatment PNI was associated with decreased OS (pooled HR $=1.68,95 \%$ CI 1.45-1.95) (Fig. 2a). Subsequent stratified analysis by cancer type for OS indicated that PNI could also be a positively predictor in RCC, BC, UTUC and PC (pooled $\mathrm{HR}=1.65,95 \% \mathrm{CI}$ 1.37-1.97, $P=0.940, I^{2}=0.0 \%$; pooled $\mathrm{HR}=1.67,95 \% \mathrm{CI}$ 1.20-2.33, $P=0.963, I^{2}=0.0 \%$; pooled $\mathrm{HR}=1.74,95 \% \mathrm{CI}$ 1.20-2.53; pooled $\mathrm{HR}=3.80,95 \% \mathrm{CI} 1.02-14.17$; respectively) (Fig. 2b). As for the treatment subgroup, a relatively lower level of PNI could be a positively predictor for OS (Surgery: $\mathrm{HR}=1.64,95 \%$ CI 1.40-1.93, $P=0.993$, $I^{2}=0.0 \%$; target therapy: $\mathrm{HR}=1.88,95 \% \mathrm{CI} 1.34-2.63$, $P=0.496, I^{2}=0.0 \%$; separately) (Fig. 2c).

\section{DFS/RFS/PFS associated with PNI in urinary cancer}

A total of ten eligible studies revealed the prognostic role of pre-treatment PNI in urinary cancers on DFS/
RFS/PFS by fixed-effects model with no heterogeneity $\left(P=0.581, I^{2}=0.0 \%\right)$. Our results indicated that a relatively lower level of pre-treatment PNI was associated with decreased DFS/RFS/PFS (pooled $\mathrm{HR}=1.75$, 95\% CI 1.53-1.99) (Fig. 3a). Subsequent stratified analysis by cancer type for DFS/RFS/PFS showed that PNI could also be a positively predictor in RCC, BC and PC (pooled HR $=1.81$, 95\% CI 1.54-2.13, $P=0.527$, $I^{2}=0.0 \%$; pooled $\mathrm{HR}=1.68, \quad 95 \%$ CI $1.32-2.12$, $P=0.985, I^{2}=0.0 \%$; pooled $\mathrm{HR}=3.50,95 \%$ CI $1.11-$ 11.07; respectively) (Fig. $3 \mathrm{~b}$ ). In the case of the treatment subgroup, a relatively lower level of PNI could be a positively predictor for DFS/RFS/PFS (surgery: $\mathrm{HR}=1.69$, 95\% CI 1.47-1.95, $P=0.683, I^{2}=0.0 \%$; target therapy: $\mathrm{HR}=2.14,95 \% \mathrm{CI} 1.50-3.05, P=0.345$, $I^{2}=6.1 \%$; separately) (Fig. 3c).

\section{CSS/DSS associated with PNI in urinary cancer}

A total of five eligible studies revealed the prognostic role of pre-treatment PNI in urinary cancer on CSS/ DSS by fixed-effects model with moderate heterogeneity $\left(P=0.147, I^{2}=41.1 \%\right)$. Our results indicated that a relatively lower level of pre-treatment PNI was associated with decreased CSS/DSS (pooled HR $=1.57$, 95\% CI 1.33-1.86) (Fig. 4a). Subsequent stratified analysis by cancer type for CSS/DSS showed that PNI could also be a positively predictor in RCC, UTUC and BC (pooled $\mathrm{HR}=1.50, \quad 95 \%$ CI $1.23-1.82, \quad P=0.952, \quad I^{2}=0.0 \%$; pooled $\mathrm{HR}=1.61, \quad 95 \%$ CI $1.13-2.28, \quad P=0.062$, $I^{2}=71.2 \%$; pooled $\mathrm{HR}=3.30,95 \%$ CI $1.44-7.59$; respectively) (Fig. 4b). 

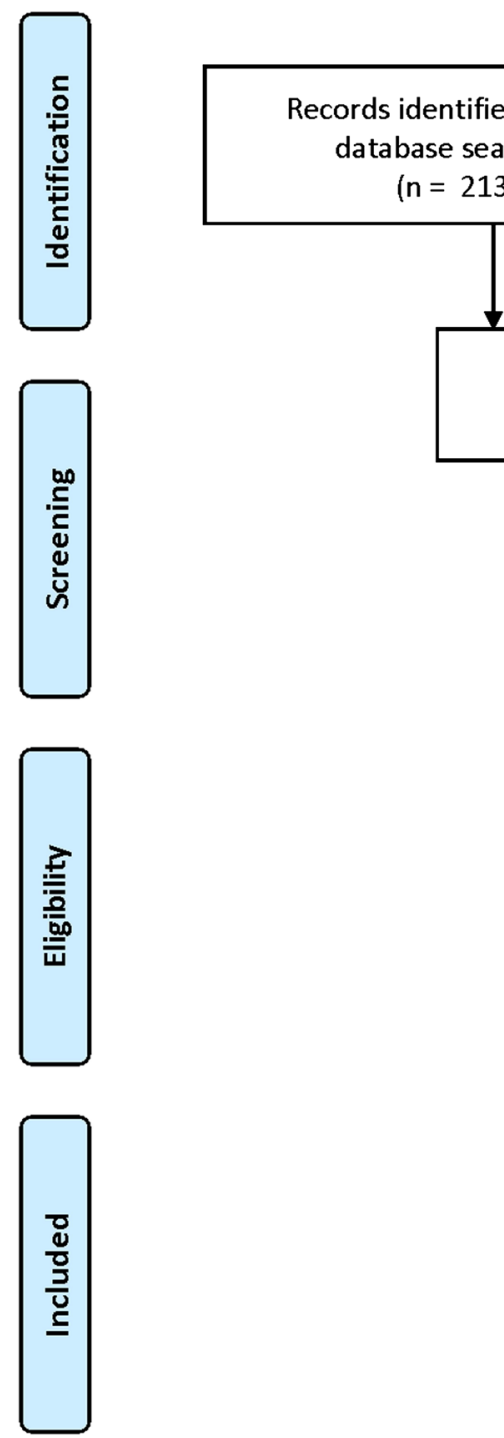

$$
\begin{aligned}
& \text { Records after duplicates removed } \\
& \qquad(\mathrm{n}=198)
\end{aligned}
$$

Additional records identified through other sources $(n=12)$

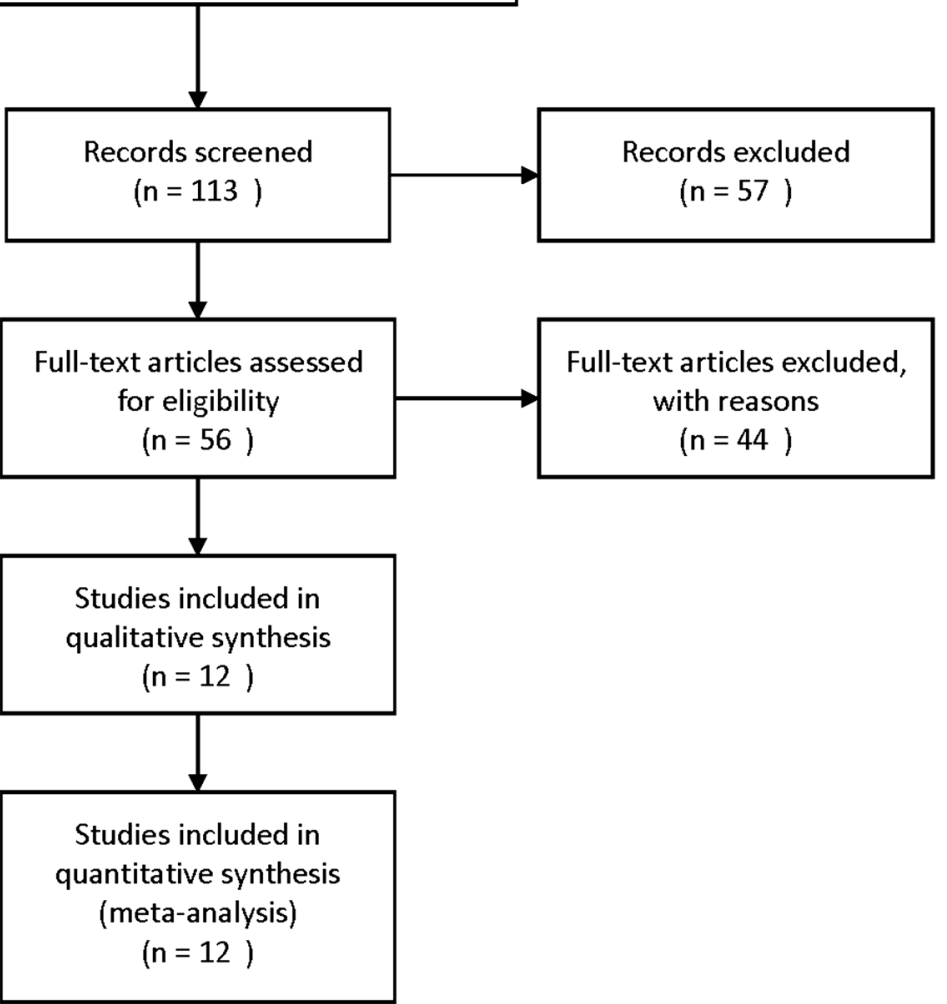

Fig. 1 Flow diagram of literature search and selection process

\section{Sensitivity analysis}

Sensitivity analysis was assessed by calculating the remained part by omitting one single study once a time to reflect the impact of the individual to overall. The sensitivity analysis of the results for pre-treatment PNI in urinary cancers indicated that no single study significantly influenced the pooled OR and 95\% CIs. Namely, our results were robust (Fig. 5).

\section{Publication bias}

As displayed in Fig. 6, publication bias was accessed by the combined application of Begg's and Egger's test. In the pooled analysis of OS or DFS/RFS/PFS or CSS/DSS, the $P$ values of them were all above 0.05 , indicating no significant bias was identified. In other words, our results were reliable based on the available articles.

\section{Discussion}

Urinary cancers had accounted for a relatively large proportion of all tumors and the newly estimated cases of PC, RCC and BC were 161,360, 63,990 and 79,030 respectively in USA, 2017 [1]. Metastases or postoperative recurrence were highly likely to occur in these tumors, for example, approximately $75 \%$ high-risk bladder cancer patients would recur, progress, or die within 10 years after their initial diagnosis [29]. Moreover, up to $20 \%$ of all RCC patients would lead to local or 
Table 2 Main characteristics of individual studies included in the meta-analysis

\begin{tabular}{|c|c|c|c|c|c|c|c|c|c|}
\hline Study & Year & Country & Cancer type & Study design & Treatment & $\begin{array}{l}\text { Number } \\
\text { of patients }\end{array}$ & Cut-off values & HR $(95 \% \mathrm{Cl})$ & $\begin{array}{l}\text { Months } \\
\text { of follow-up }\end{array}$ \\
\hline \multicolumn{10}{|c|}{ Overall survival (OS) } \\
\hline Cai [18] & 2017 & China & $\mathrm{RCC}$ & Retrospective & Target therapy & 178 & 51.62 & $\begin{array}{l}1.658(1.04- \\
2.641)\end{array}$ & $\begin{array}{l}22 \text { months } \\
\text { median }\end{array}$ \\
\hline Peng [25] & 2017 & China & $\mathrm{BC}$ & Retrospective & $\mathrm{RC}$ & 516 & $46.025 / 47.2$ & $\begin{array}{l}1.668(1.147- \\
2.425)\end{array}$ & $\begin{array}{l}37 \text { months } \\
\text { median }\end{array}$ \\
\hline Miyake [24] & 2017 & Japan & $B C$ & Retrospective & $\mathrm{RC}$ & 117 & 50 & $1.70(0.80-3.30)$ & $\begin{array}{l}22 \text { months } \\
\text { median }\end{array}$ \\
\hline Huang [26] & 2017 & China & UTUC & Retrospective & RNU & 425 & 46.78 & $1.74(1.20-2.53)$ & $\begin{array}{l}38.5 \text { months } \\
\text { median }\end{array}$ \\
\hline Fan [28] & 2017 & China & PC & Retrospective & Target therapy & 112 & 50.5 & $3.80(1.00-13.9)$ & $\begin{array}{l}20.2 \text { months } \\
\text { median }\end{array}$ \\
\hline Broggi [17] & 2016 & American & $\mathrm{RCC}$ & Retrospective & Nephrectomy & 341 & 44.7 & $1.73(1.09-2.76)$ & $N R$ \\
\hline Kwon [21] & 2017 & Korea & $\mathrm{RCC}$ & Retrospective & Target therapy & 125 & 41 & $1.96(1.16-3.33)$ & $\begin{array}{l}45.3 \text { months } \\
\text { median }\end{array}$ \\
\hline Peng [22] & 2017 & China & $\mathrm{RCC}$ & Retrospective & Nephrectomy & 1360 & $47.625 / 47.775$ & $\begin{array}{l}1.645(1.153- \\
2.348)\end{array}$ & $\begin{array}{l}67 \text { months } \\
\text { median }\end{array}$ \\
\hline Jeon [20] & 2016 & Korea & $\mathrm{RCC}$ & Retrospective & PN, RN & 1437 & 51 & $1.50(1.09-2.07)$ & $\begin{array}{l}68.6 \text { months } \\
\text { mean }\end{array}$ \\
\hline \multicolumn{10}{|c|}{ Progression/disease/recurrence-free survival (PFS/DFS/RFS) } \\
\hline Cai [18] & 2017 & China & $\mathrm{RCC}$ & Retrospective & Target therapy & 178 & 51.62 & $\begin{array}{l}1.842(1.226- \\
2.766)\end{array}$ & $\begin{array}{l}22 \text { months } \\
\text { median }\end{array}$ \\
\hline Peng [25] & 2017 & China & $\mathrm{BC}$ & Retrospective & $\mathrm{RC}$ & 516 & $46.025 / 47.2$ & $\begin{array}{l}1.68(1.092- \\
2.005)\end{array}$ & $\begin{array}{l}37 \text { months } \\
\text { median }\end{array}$ \\
\hline Cui [23] & 2017 & China & $\mathrm{BC}$ & Retrospective & TURBT & 329 & 52.57 & $\begin{array}{l}1.672(1.149- \\
2.439)\end{array}$ & $\begin{array}{l}43.9 \pm 27.1 \\
\quad(\text { mean } \pm S D)\end{array}$ \\
\hline Fan [28] & 2017 & China & PC & Retrospective & Target therapy & 112 & 50.5 & $3.50(1.10-11.0)$ & $\begin{array}{l}20.2 \text { months } \\
\text { median }\end{array}$ \\
\hline Broggi [17] & 2016 & American & RCC & Retrospective & Nephrectomy & 341 & 44.7 & $2.26(1.42-3.73)$ & NR \\
\hline Kwon [21] & 2017 & Korea & RCC & Retrospective & Target therapy & 125 & 41 & $3.33(1.35-8.33)$ & $\begin{array}{l}45.3 \text { months } \\
\text { median }\end{array}$ \\
\hline Peng [22] & 2017 & China & RCC & Retrospective & Nephrectomy & 1360 & $47.625 / 47.775$ & $\begin{array}{l}1.705(1.266- \\
2.296)\end{array}$ & $\begin{array}{l}67 \text { months } \\
\text { median }\end{array}$ \\
\hline Kim [27] & 2015 & Korea & UTUC & Retrospective & $\mathrm{NU}$ & 277 & 45 & $\begin{array}{l}1.183(0.656- \\
2.132)\end{array}$ & $\begin{array}{l}57.2 \text { months } \\
\text { median }\end{array}$ \\
\hline Jeon [20] & 2016 & Korea & $\mathrm{RCC}$ & Retrospective & PN, RN & 1437 & 51 & $1.47(1.03-2.11)$ & $\begin{array}{l}68.6 \text { months } \\
\text { mean }\end{array}$ \\
\hline Hofbauer [19] & 2015 & Austria & $\mathrm{RCC}$ & Retrospective & PN, RN & 1344 & 48 & $1.96(1.32-2.86)$ & $\begin{array}{l}40 \text { months } \\
\text { median }\end{array}$ \\
\hline \multicolumn{10}{|c|}{ Cancer/disease-specific survival (CSS/DSS) } \\
\hline Miyake [24] & 2017 & Japan & $B C$ & Retrospective & $\mathrm{RC}$ & 117 & 50 & $3.30(1.40-7.40)$ & $\begin{array}{l}22 \text { months } \\
\text { median }\end{array}$ \\
\hline Huang [26] & 2017 & China & UTUC & Retrospective & RNU & 425 & 46.78 & $1.98(1.31-2.99)$ & $\begin{array}{l}38.5 \text { months } \\
\text { median }\end{array}$ \\
\hline Jeon [20] & 2016 & Korea & $\mathrm{RCC}$ & Retrospective & PN, RN & 1437 & 51 & $1.51(1.05-2.19)$ & $\begin{array}{l}68.6 \text { months } \\
\text { mean }\end{array}$ \\
\hline Kim [27] & 2015 & Korea & UTUC & Retrospective & $\mathrm{NU}$ & 277 & 45 & $\begin{array}{l}0.947(0.491- \\
1.826)\end{array}$ & $\begin{array}{l}57.2 \text { months } \\
\text { median }\end{array}$ \\
\hline Hofbauer [19] & 2015 & Austria & $\mathrm{RCC}$ & Retrospective & PN, RN & 1344 & 48 & $1.49(1.19-1.89)$ & $\begin{array}{l}40 \text { months } \\
\text { median }\end{array}$ \\
\hline
\end{tabular}




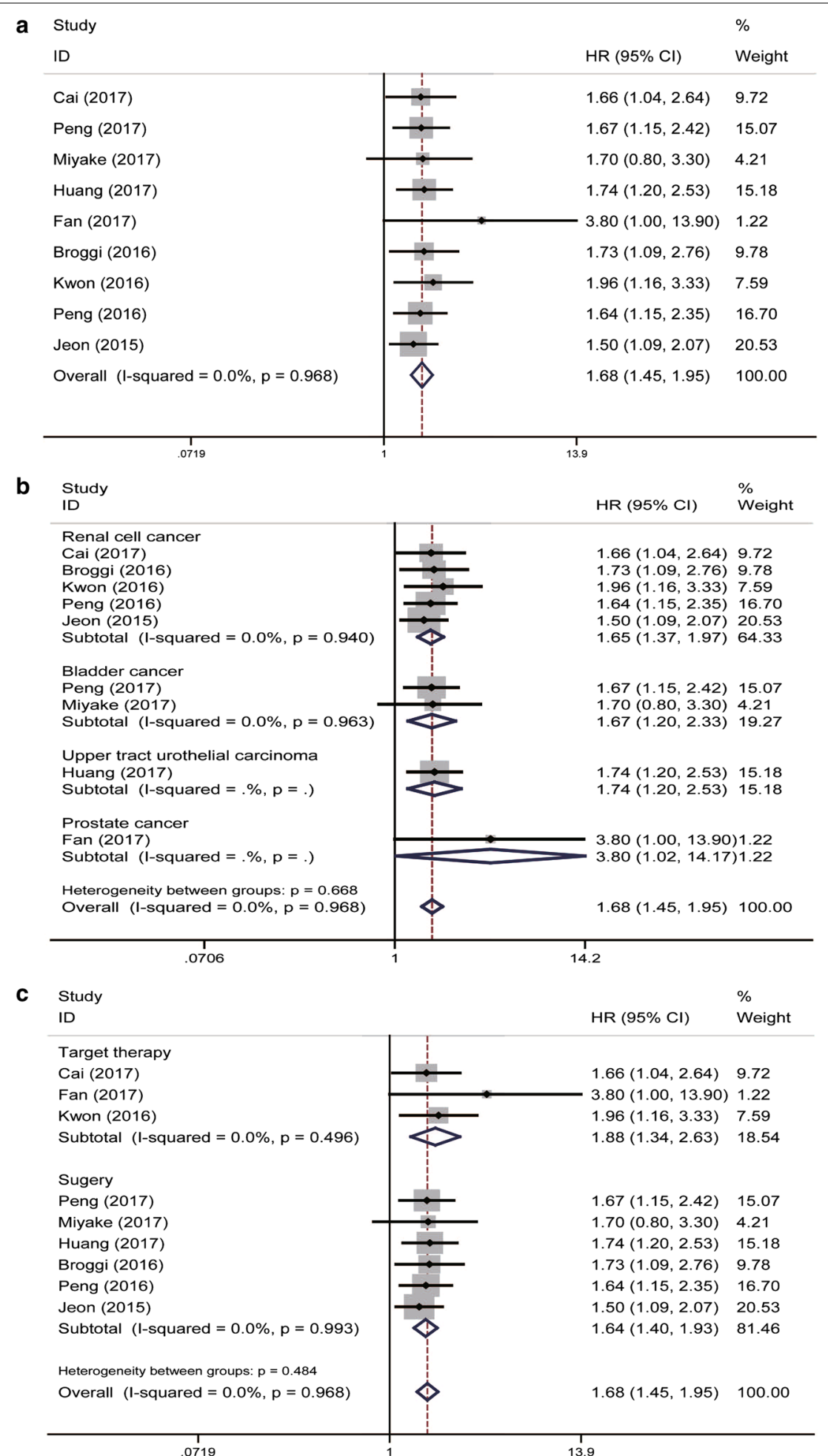

Fig. 2 Forrest plots of OS associated with PNI in urinary cancers. a The overall group; $\mathbf{b}$ the subgroup analysis of cancer type; c the subgroup analysis of treatment type 


\begin{tabular}{|c|c|c|c|}
\hline \multicolumn{2}{|l|}{ Study } & \multirow[b]{2}{*}{$\operatorname{HR}(95 \% \mathrm{Cl})$} & \multirow{2}{*}{$\begin{array}{l}\% \\
\text { Weigh }\end{array}$} \\
\hline ID & & & \\
\hline Cai (2017) & $\rightarrow$ & $1.84(1.23,2.77)$ & 10.27 \\
\hline Peng (2017) & $\longrightarrow$ & $1.68(1.09,2.01)$ & 18.42 \\
\hline Cui (2017) & & $1.67(1.15,2.44)$ & 12.00 \\
\hline Fan (2017) & & $-3.50(1.10,11.00)$ & 1.28 \\
\hline Broggi (2016) & & $2.26(1.42,3.73)$ & 7.29 \\
\hline Kwon (2016) & & $3.33(1.35,8.33)$ & 2.05 \\
\hline Peng (2016) & & $1.71(1.27,2.30)$ & 19.19 \\
\hline Kim (2015) & $\rightarrow$ & $1.18(0.66,2.13)$ & 4.89 \\
\hline Jeon (2015) & $\rightarrow$ & $1.47(1.03,2.11)$ & 13.22 \\
\hline Hofbauer (2014) & & $1.96(1.32,2.86)$ & 11.37 \\
\hline Overall $(I-$ squared $=0.0 \%, p=0.581$ ) & $\Rightarrow$ & $1.75(1.53,1.99)$ & 100.00 \\
\hline
\end{tabular}

b Study

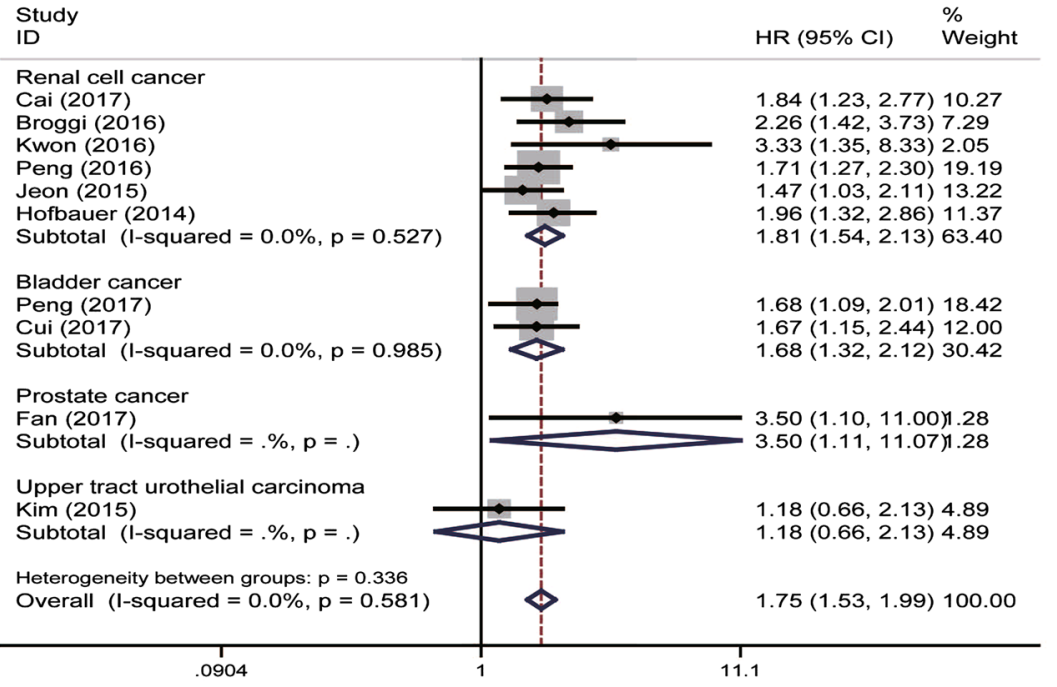

C Study

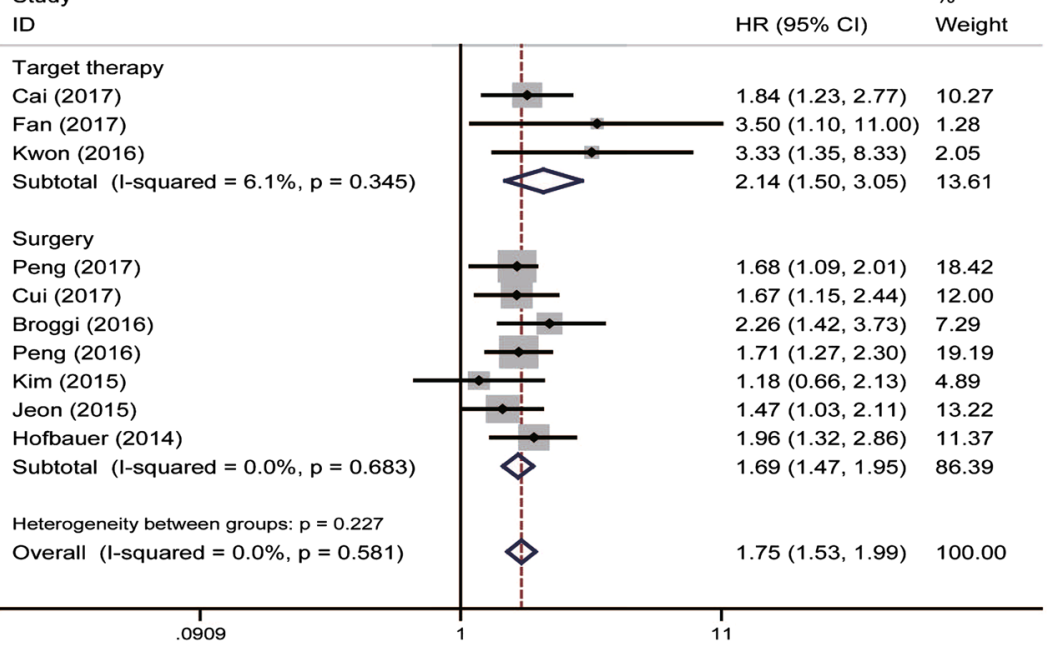

Fig. 3 Forrest plots of DFS/RFS/PFS associated with PNI in urinary cancers. a The overall group; $\mathbf{b}$ the subgroup analysis of cancer type; $\mathbf{c}$ the subgroup analysis of treatment type 

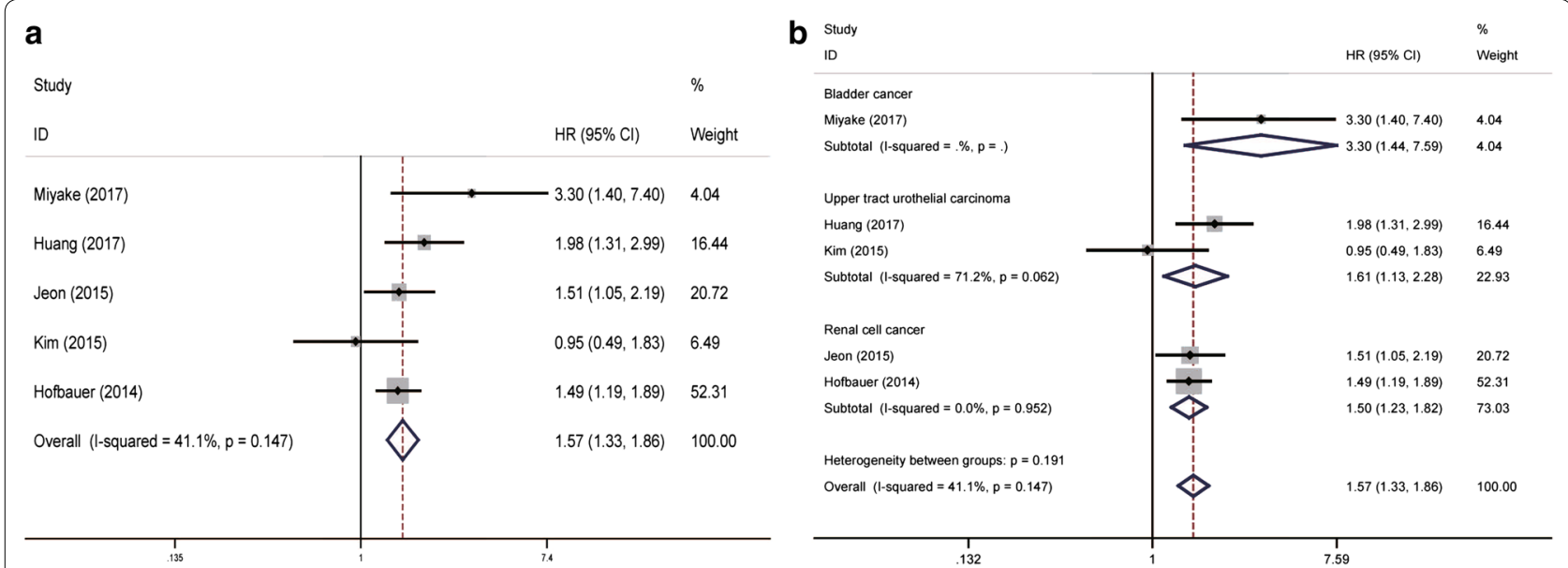

Fig. 4 Forrest plots of CSS/DSS associated with PNI in urinary cancers. a The overall group; $\mathbf{b}$ the subgroup analysis of cancer type

distant disease recurrence ultimately [30]. Once metastasized, the 5-year survival rate was less than $10 \%$ [31]. Obviously, it was utmostly important to identify the prognostic factors in urinary tumors. To our best knowledge, it was the first meta-analysis to estimate the prognostic role of pre-treatment PNI in urinary cancers.

Accumulating data had been widely investigated for a long time on the prediction of tumor survival and recurrence. The host inflammatory response had already been proved to be a predictor of survival independent of stage and grade in many solid tumors [32,33]. Existing hypothesis claimed that this process was suitable for the tumor growth in their microenvironment, based on its provision of growth factors, proangiogenic factors or extracellular matrix enzymes [34]. On the other hand, the cancer stem cell pathway could also be activated by inflammatory cytokines, which could promote the development and invasion of the tumor [35]. In terms of these, the prognostic role of $\mathrm{C}$-reactive protein in $\mathrm{RCC}$ had been confirmed [36]. Furthermore, the host nutritional status was considered to be closely related to tumor prognosis. In 2009, Karl et al. [37] made an evaluation in 897 urologic patients utilizing the Nutritional Risk Screening 2002 (NRS), claimed that $16 \%$ of patients were under the risk of malnutrition, which can contribute to malignant disease. Gregg et al. [38] found a simple model, measured by body mass index (BMI), serum albumin and preoperative weight loss, that which can predict 90-day mortality and poor OS at 3 years in BC patients. Additionally, a study conducted by Lambert et al. [39] demonstrated that the pre-treatment albumin levels had something to do with higher mortality. However, there is no unified and approved standard to reflect the nutritional status of preoperative patients.
Past researches had revealed that many factors could be investigated to predict the prognosis in urinary tumors. Pre-treatment neutrophil-to-lymphocyte (NLR) ratio and pre-treatment lymphocyte-monocyte ratio (LMR) had been proved to be an independent prognostic factor in various urinary cancers [40-42]. Generally, high pre-treatment NLR or LMR was closely associated with poor survival. Santoni et al. [43] thought pre-treatment NLR to be an independent prognostic factor for mRCC patients treated with second- or third-line everolimus. Yoshida et al. [44] found that pre-treatment lower level LMR could predict poorer OS and CSS by analyzing 302 patients underwent radical cystectomy. Meanwhile, the potential role of LMR may superior to NLR to some extent. Similarly, the potential role of Glasgow prognostic score (GPS) [45] and systemic immune-inflammation index (SII) [46] had also been explored.

In this meta-analysis, conclusion could be drawn that a relatively lower pre-treatment PNI was tightly associated with a poorer OS, DFS/PFS/RFS and CSS/DSS. Subgroup analysis by cancer type or treatment type showed the similar results. PNI, calculated by serum albumin levels and lymphocyte count and its accurate value equals to 10 * serum albumin concentration $(\mathrm{g} /$ $\mathrm{dL})+0.005$ " lymphocyte counts (number $/ \mathrm{mm}^{2}$ ), was first applied by Onodera et al. [7] to assess the nutritional and immunological status of gastrointestinal surgical patients. Serum albumin, known as an indicator of host inflammatory and nutritional status, had been verified its prognostic role in various types of cancers $[47,48]$. In addition, the host immune response activated by lymphocytes can help clearance of the tumor cells or prevent them from developing [34], the lower level of lymphocytes may represent a poorer survival or a higher mortality [49]. Therefore, it was easy to explain 
$\mathbf{a}$ Meta-analysis estimates, given named study is omitted Lower Cl Limit O Ostimate Upper Cl Limit

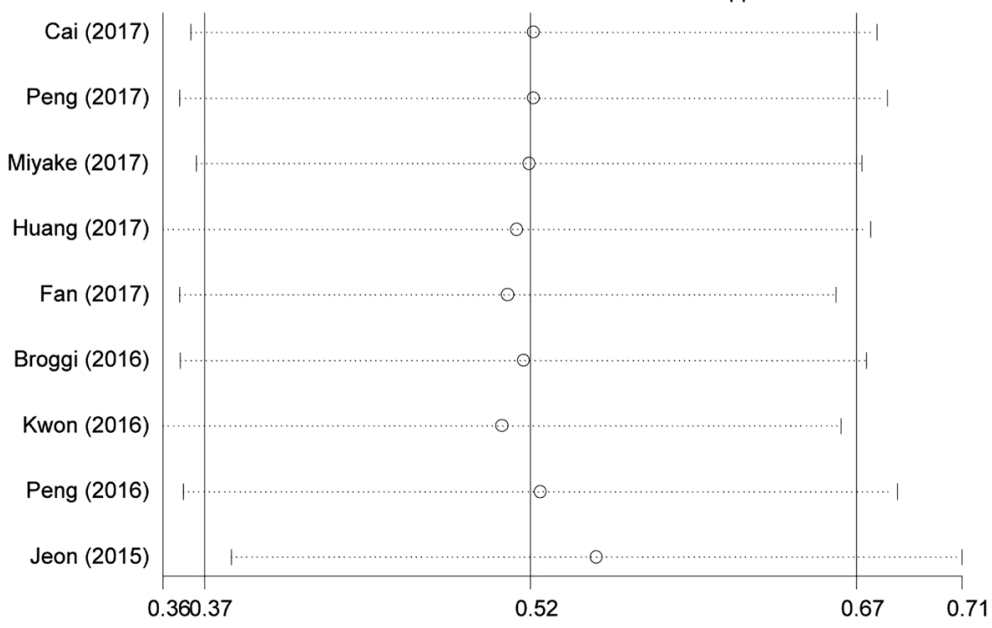

b

Meta-analysis estimates, given named study is omitted
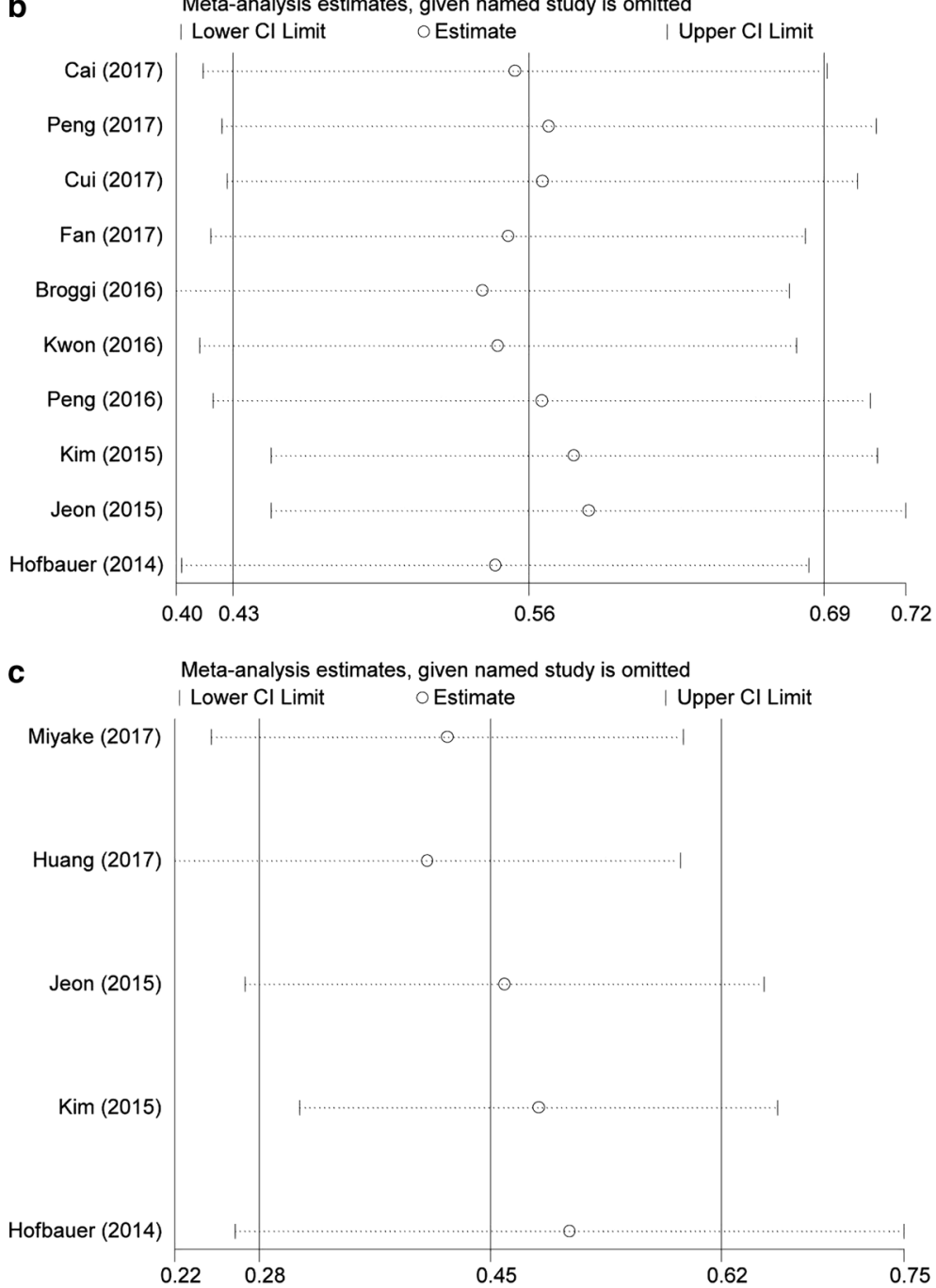

Fig. 5 Sensitivity analysis of each included study. a OS for individual studies; $\mathbf{b}$ DFS/RFS/PFS for individual studies; $\mathbf{c}$ CSS/DSS for individual studies 

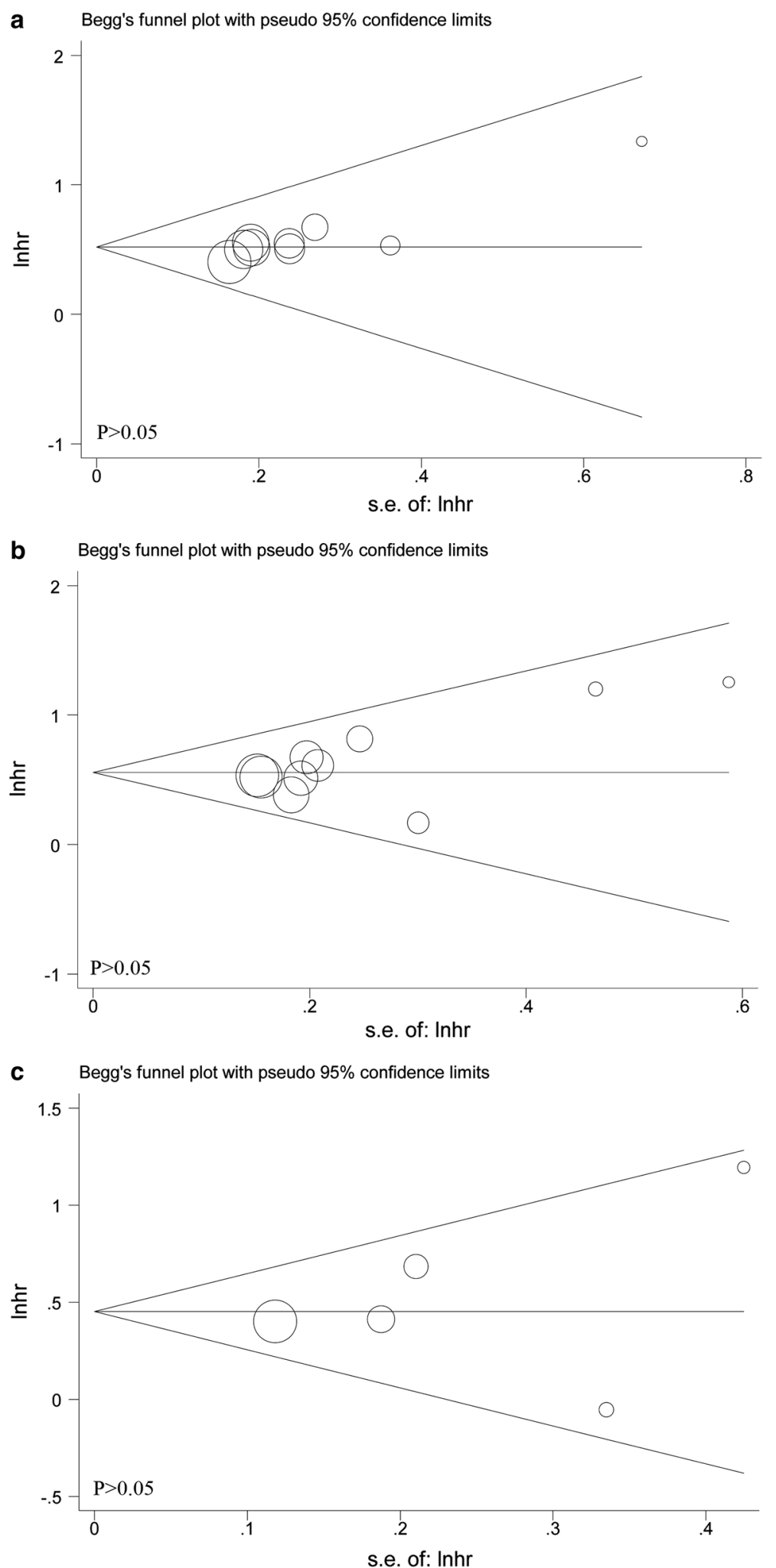

Fig. 6 Begg's funnel plots of the publication bias. a OS for individual studies; b DFS/RFS/PFS for individual studies; c CSS/DSS for individual studies 
that why the PNI level, determined by serum albumin and lymphocytes, played an important role in prognosis of urinary tumors. In our study, a lower level of PNI may indicate a poorer survival and higher possibility of recurrence in urinary tumors regardless of its tumor type and treatment.

During our selection process, only one article focused on the relationship between PNI and prostate cancer [28]. In that research, Fan and his team assessed the prognostic role of PNI in prostate cancer treated with abiraterone (AA), a high baseline PNI level was tightly related to the initial response to AA treatment in metastatic castration-resistant prostate cancer patients (mCRPC), and the lower PNI level may predict poorer OS, radiographic PFS (rPFS), PSA-PFS. Furthermore, add PNI into the prediction model could increase the accuracy of a multivariate model for OS.

The strength of our study was mainly its strict inclusion criteria for eligible studies and the entire heterogeneity was relatively low. In addition, it was the first time for us to shed light on the prognostic role of pretreatment PNI in urinary cancers. Nonetheless, several potential limitations should be paid attention to before fully understanding this study. Firstly, uncontrollable bias may exist because all of the included articles were retrospective studies rather than randomized controlled trials. Secondly, related articles were too few to obtain a reliable result in some specific endpoints (e.g. only five articles included in the analysis for CSS/DSS). Due to the relatively small sample size, unavoidable bias might also exist. Thirdly, most of the included articles were from Asia which may make the subgroup analysis hard to be performed. Last but not least, upcoming prospective RCTs were required to provide more available data and subsequent researches should resolve the aforementioned difficulties before pretreatment PNI was widely used in clinical practice.

\section{Conclusion}

In summary, the outcomes of this meta-analysis shed light on that a higher level of pre-treatment PNI was positively associated with OS, CSS/DSS and DFS/RFS/ PFS, indicating that it could be an independent prognostic factor in urinary tumors. Due to the limited researches, it restricted our in-depth investigation of the role of PNI. Hence, larger-samples with higherquality randomized controlled trials were required to verify our findings.

\section{Authors' contributions}

YJ, NHS: protocol/project development; YMW, YCW: data collection or management; RC, QJZ: data analysis; FQ, XZ, YW: manuscript writing/editing. All authors read and approved the final manuscript.

\section{Acknowledgements}

We would like to thank the researchers and study participants for their contributions.

\section{Competing interests}

The authors declare that they have no competing interests.

\section{Availability of data and materials}

All the data (pooled hazard ratios with 95\% confidence intervals of OS or DFS/ PFS/RFS or (SS/DSS) used to support the findings of this study are included within the article. Please contact author for data requests.

\section{Consent for publication}

Not applicable.

\section{Ethics approval and consent to participate}

Not applicable.

\section{Funding}

This article was funded by Medical key talent of Jiangsu Province: ZDRCA2016009 and the National Natural Science Foundation of China (Grant Number: 81871151). The corresponding author had full access to all the data in the study and had final responsibility for the decision to submit for publication.

\section{Publisher's Note}

Springer Nature remains neutral with regard to jurisdictional claims in published maps and institutional affiliations.

Received: 27 August 2018 Accepted: 11 December 2018

Published online: 17 December 2018

\section{References}

1. Siegel RL, Miller KD, Jemal A. Cancer statistics, 2017. CA Cancer J Clin. 2017:67(1):7-30.

2. Escudier B, Eisen T, Stadler WM, Szczylik C, Oudard S, Siebels M, Negrier S, Chevreau C, Solska E, Desai AA, et al. Sorafenib in advanced clear-cell renal-cell carcinoma. N Engl J Med. 2007;356(2):125-34.

3. Rini BI, Escudier B, Tomczak P, Kaprin A, Szczylik C, Hutson TE, Michaelson MD, Gorbunova VA, Gore ME, Rusakov IG, et al. Comparative effectiveness of axitinib versus sorafenib in advanced renal cell carcinoma (AXIS): a randomised phase 3 trial. Lancet. 2011;378(9807):1931-9.

4. Kantoff PW, Higano CS, Shore ND, Berger ER, Small EJ, Penson DF, Redfern $\mathrm{CH}$, Ferrari AC, Dreicer R, Sims RB, et al. Sipuleucel-T immunotherapy for castration-resistant prostate cancer. N Engl J Med. 2010;363(5):411-22.

5. Cohen HT, McGovern FJ. Renal-cell carcinoma. N Engl J Med. 2005;353(23):2477-90.

6. DeSantis CE, Lin CC, Mariotto AB, Siegel RL, Stein KD, Kramer JL, Alteri R, Robbins AS, Jemal A. Cancer treatment and survivorship statistics, 2014 CA Cancer J Clin. 2014;64(4):252-71.

7. Onodera T, Goseki N, Kosaki G. Prognostic nutritional index in gastrointestinal surgery of malnourished cancer patients. Nihon Geka Gakkai zasshi. 1984:85(9):1001-5.

8. Pinato DJ, North BV, Sharma R. A novel, externally validated inflammationbased prognostic algorithm in hepatocellular carcinoma: the prognostic nutritional index (PNI). Br J Cancer. 2012;106(8):1439-45.

9. Kanda M, Fujii T, Kodera Y, Nagai S, Takeda S, Nakao A. Nutritional predictors of postoperative outcome in pancreatic cancer. Br J Surg. 2011;98(2):268-74.

10. Yao ZH, Tian GY, Wan YY, Kang YM, Guo HS, Liu QH, Lin DJ. Prognostic nutritional index predicts outcomes of malignant pleural mesothelioma. J Cancer Res Clin Oncol. 2013;139(12):2117-23.

11. Moher D, Shamseer L, Clarke M, Ghersi D, Liberati A, Petticrew M, Shekelle P, Stewart LA, Group P-P. Preferred reporting items for systematic review and meta-analysis protocols (PRISMA-P) 2015 statement. Syst Rev. 2015:4:1. 
12. Williamson PR, Smith CT, Hutton JL, Marson AG. Aggregate data metaanalysis with time-to-event outcomes. Stat Med. 2002;21 (22):3337-51.

13. Tierney JF, Stewart LA, Ghersi D, Burdett S, Sydes MR. Practical methods for incorporating summary time-to-event data into meta-analysis. Trials. 2007;8:16.

14. Stang A. Critical evaluation of the Newcastle-Ottawa scale for the assessment of the quality of nonrandomized studies in meta-analyses. Eur J Epidemiol. 2010;25(9):603-5

15. DerSimonian R, Kacker R. Random-effects model for meta-analysis of clinical trials: an update. Contemp Clin Trials. 2007;28(2):105-14.

16. Egger M, Davey Smith G, Schneider M, Minder C. Bias in meta-analysis detected by a simple, graphical test. BMJ. 1997;315(7109):629-34.

17. Broggi MS, Patil D, Baum Y, Nieh PT, Alemozaffar M, Pattaras JG, Ogan $\mathrm{K}$, Master VA. Onodera's prognostic nutritional index as an independent prognostic factor in clear cell renal cell carcinoma. Urology. 2016;96:99-105

18. Cai W, Zhong H, Kong W, Dong B, Chen Y, Zhou L, Xue W, Huang Y, Zhang J, Huang J. Significance of preoperative prognostic nutrition index as prognostic predictors in patients with metastatic renal cell carcinoma with tyrosine kinase inhibitors as first-line target therapy. Int Urol Nephrol. 2017:49(11):1955-63.

19. Hofbauer SL, Pantuck AJ, de Martino M, Lucca I, Haitel A, Shariat SF, Belldegrun AS, Klatte T. The preoperative prognostic nutritional index is an independent predictor of survival in patients with renal cell carcinoma. Urol Oncol. 2015;33(2):68.e61-7.

20. Jeon $H G$, Choi DK, Sung HH, Jeong BC, Seo SI, Jeon SS, Choi HY, Lee HM. Preoperative prognostic nutritional index is a significant predictor of survival in renal cell carcinoma patients undergoing nephrectomy. Ann Surg Oncol. 2016;23(1):321-7.

21. Kwon WA, Kim S, Kim SH, Joung JY, Seo HK, Lee KH, Chung J. Pretreatment prognostic nutritional index is an independent predictor of survival in patients with metastatic renal cell carcinoma treated with targeted therapy. Clin Genitourin Cancer. 2017;15(1):100-11.

22. Peng D, He ZS, Li XS, Tang Q, Zhang L, Yang KW, Yu XT, Zhang CJ, Zhou $L Q$. Prognostic value of inflammatory and nutritional scores in renal cell carcinoma after nephrectomy. Clin Genitourin Cancer. 2017;15(5):582-90.

23. Cui J, Chen S, Bo Q, Wang S, Zhang N, Yu M, Wang W, Han J, Zhu Y, Shi B. Preoperative prognostic nutritional index and nomogram predicting recurrence-free survival in patients with primary non-muscleinvasive bladder cancer without carcinoma in situ. Onco Targets Ther. 2017;10:5541-50.

24. Miyake M, Morizawa Y, Hori S, Marugami N, lida K, Ohnishi K, Gotoh D, Tatsumi Y, Nakai Y, Inoue T, et al. Integrative assessment of pretreatment inflammation-, nutrition-, and muscle-based prognostic markers in patients with muscle-invasive bladder cancer undergoing radical cystectomy. Oncology. 2017;93(4):259-69.

25. Peng D, Gong YQ, Hao H, He ZS, Li XS, Zhang CJ, Zhou LQ. Preoperative prognostic nutritional index is a significant predictor of survival with bladder cancer after radical cystectomy: a retrospective study. BMC Cancer. 2017;17(1):391.

26. Huang J, Yuan Y, Wang Y, Chen Y, Kong W, Xue W, Chen H, Zhang J, Huang Y. Preoperative prognostic nutritional index is a significant predictor of survival in patients with localized upper tract urothelial carcinoma after radical nephroureterectomy. Urol Oncol. 2017. https://doi.org/10.1016/j. urolonc.2017.07.028.

27. Kim M, Moon KC, Choi WS, Jeong CW, Kwak C, Kim HH, Ku JH. Prognostic value of systemic inflammatory responses in patients with upper urinary tract urothelial carcinoma. World J Urol. 2015;33(10):1439-57.

28. Fan L, Wang X, Chi C, Wang Y, Cai W, Shao X, Xu F, Pan J, Zhu Y, Shangguan $X$, et al. Prognostic nutritional index predicts initial response to treatment and prognosis in metastatic castration-resistant prostate cancer patients treated with abiraterone. Prostate. 2017;77(12):1233-41.

29. Chamie K, Litwin MS, Bassett JC, Daskivich TJ, Lai J, Hanley JM, Konety BR, Saigal CS, Urologic diseases in America P. recurrence of high-risk bladder cancer: a population-based analysis. Cancer. 2013;119(17):3219-27.
30. Brookman-May SD, May M, Shariat SF, Novara G, Zigeuner R, Cindolo L, De Cobelli O, De Nunzio C, Pahernik S, Wirth MP, et al. Time to recurrence is a significant predictor of cancer-specific survival after recurrence in patients with recurrent renal cell carcinoma-results from a comprehensive multi-centre database (CORONA/SATURN-Project). BJU Int. 2013;112(7):909-16.

31. Ljungberg B, Campbell SC, Choi HY, Jacamin D, Lee JE, Weikert S, Kiemeney LA. The epidemiology of renal cell carcinoma. Eur Urol. 2011;60(4):615-21.

32. Coussens $L M$, Werb Z. Inflammation and cancer. Nature. 2002:420(6917):860-7.

33. Vakkila J, Lotze MT. Inflammation and necrosis promote tumour growth. Nat Rev Immunol. 2004;4(8):641-8.

34. Hanahan D, Weinberg RA. Hallmarks of cancer: the next generation. Cell. 2011;144(5):646-74.

35. Shigdar S, Li Y, Bhattacharya S, O'Connor M, Pu C, Lin J, Wang T, Xiang D, Kong L, Wei MQ, et al. Inflammation and cancer stem cells. Cancer Lett. 2014;345(2):271-8.

36. Karakiewicz PI, Hutterer GC, Trinh QD, Jeldres C, Perrotte P, Gallina A, Tostain J, Patard JJ. C-reactive protein is an informative predictor of renal cell carcinoma-specific mortality: a European study of 313 patients. Cancer. 2007;110(6):1241-7.

37. Karl A, Rittler P, Buchner A, Fradet V, Speer R, Walther S, Stief GC. Prospective assessment of malnutrition in urologic patients. Urology. 2009;73(5):1072-6.

38. Gregg JR, Cookson MS, Phillips S, Salem S, Chang SS, Clark PE, Davis R, Stimson CJ Jr, Aghazadeh M, Smith JA Jr, et al. Effect of preoperative nutritional deficiency on mortality after radical cystectomy for bladder cancer. J Urol. 2011;185(1):90-6.

39. Lambert JW, Ingham M, Gibbs BB, Given RW, Lance RS, Riggs SB. Using preoperative albumin levels as a surrogate marker for outcomes after radical cystectomy for bladder cancer. Urology. 2013;81(3):587-92.

40. Hu K, Lou L, Ye J, Zhang S. Prognostic role of the neutrophil-lymphocyte ratio in renal cell carcinoma: a meta-analysis. BMJ Open. 2015;5(4):e006404.

41. Sang L, Wang XM, Xu DY, Cai YF. Accuracy of shear wave elastography for the diagnosis of prostate cancer: a meta-analysis. Sci Rep. 2017;7(1):1949.

42. Li X, Ma X, Tang L, Wang B, Chen L, Zhang F, Zhang X. Prognostic value of neutrophil-to-lymphocyte ratio in urothelial carcinoma of the upper urinary tract and bladder: a systematic review and meta-analysis. Oncotarget. 2017;8(37):62681-92.

43. Vanderschuren $L$, Trezza $V$. What the laboratory rat has taught us about social play behavior: role in behavioral development and neural mechanisms. Curr Top Behav Neurosci. 2014;16:189-212.

44. Yoshida T, Kinoshita H, Yoshida K, Mishima T, Yanishi M, Inui H, Komai Y, Sugi M, Inoue T, Murota T, et al. Prognostic impact of perioperative lymphocyte-monocyte ratio in patients with bladder cancer undergoing radical cystectomy. Tumour Biol. 2016;37(8):10067-74.

45. Shim SR, Kim SJ, Kim SI, Cho DS. Prognostic value of the Glasgow Prognostic Score in renal cell carcinoma: a meta-analysis. World J Urol. 2017:35(5):771-80

46. Lolli C, Caffo O, Scarpi E, Aieta M, Conteduca V, Maines F, Bianchi E, Massari F, Veccia A, Chiuri VE, et al. Systemic immune-inflammation index predicts the clinical outcome in patients with $M C R P C$ treated with abiraterone. Front Pharmacol. 2016;7:376.

47. Stenman M, Laurell A, Lindskog M. Prognostic significance of serum albumin in patients with metastatic renal cell carcinoma. Med Oncol. 2014;31(3):841.

48. Han S, Huang Y, Li Z, Hou H, Wu A. The prognostic role of preoperative serum albumin levels in glioblastoma patients. BMC Cancer. 2015;15:108.

49. Ray-Coquard I, Cropet C, Van Glabbeke M, Sebban C, Le Cesne A, Judson I, Tredan O, Verweij J, Biron P, Labidi I, et al. Lymphopenia as a prognostic factor for overall survival in advanced carcinomas, sarcomas, and lymphomas. Can Res. 2009:69(13):5383-91. 